\title{
Can Integration of Legume Trees Increase Yield Stability in Rain-fed Maize Cropping Systems in Southern Africa?
}

\author{
Gudeta W. Sileshi \\ World Agroforestry Centre (ICRAF), Southern Africa Regional Programme, Chitedze Agricultural Research Station, \\ P.O. Box 30798, Lilongwe, Malawi;
}

Legesse Kassa Debusho

University of Pretoria, Department of Statistics, Private Bag X20, Hatfield 0028, South Africa

Festus K. Akinnifesi

3334 Marvin D. Love Freeway, CFNI, Morning Star (Apt.122b), Dallas, TX 75224

\begin{abstract}
Growing maize (Zea mays) in association with legume tree in agroforestry arrangements has been shown to increase yields in many parts of sub-Saharan Africa (SSA). However, the stability of crop yields has not been critically analyzed in the various cropping systems that integrate leguminous trees. The objective of this analysis was to compare yield stability in improved cropping systems, namely maize-Gliricidia (Gliricidia sepium) intercropping and fertilized monoculture maize, with the de facto practice of resource-poor farmers who grow maize continuously without any external input. Yield stability was determined for three long-term field trials (12-13 consecutive years) conducted at Makoka Research Station in southern Malawi and Msekera Research Station in eastern Zambia. At Makoka, the most stable yield was recorded in maize-Gliricidia intercrops. Average yield was highest in maize-Gliricidia intercropping amended with $50 \%$ of the recommended $\mathrm{N}$ and $\mathrm{P}$ fertilizer, and this was comparable with yield recorded in monoculture maize that received inorganic fertilizer. On the two sites at Msekera, the highest yield was recorded in fertilized monoculture maize followed by maize-Gliricidia intercrops. However, yields were more stable in maizeGliricidia intercropping compared to fertilized maize on both sites at Msekera. It is concluded that maize yields remain more stable in maize-Gliricidia intercropping than in fertilized maize monoculture in the longterm although average yields may be higher with full fertilization.
\end{abstract}

Key words: Agroforestry, Cropping system, Gliricidia sepium, land degradation, soil fertility 


\section{INTRODUCTION}

More than $95 \%$ of the farm land in sub-Saharan Africa (SSA) is rain-fed, and crop yields are generally low and variable as a consequence of variable rainfall, drought and land degradation (Wani et al., 2009). Maize accounts for over $50 \%$ of the cropped area and the calories consumed in many countries in SSA (Sileshi et al., 2010). The maize mixed farming system, which covers $10 \%$ of the land area in SSA, is currently in crisis (Dixon et al., 2001). As a result of rapid population growth, average farm sizes have fallen to under 0.5 ha in many parts of the region. The soils have also been subjected to erosion, loss of organic matter and serious fertility decline (Sanchez, 2002). Input use has fallen sharply due to increasing price. There are also signs of increasing soil acidity in some instances where there has been continuous cultivation, prolonged use of inorganic fertilizers and burning of crop residues (Munthali, 2007). Consequently maize yields have either stagnated or are in a state of decline. With climate change, maize cropping systems are also expected to experience a remarkable reduction in yield (Lobell et al., 2011). For $1{ }^{\circ} \mathrm{C}$ of warming alone more than $75 \%$ of the present maize-growing areas in Africa are predicted to experience at least $20 \%$ reduction in yield under drought conditions (Lobell et al., 2011).

Land degradation can exacerbate drought as the former affects water availability, quality, and storage (Bossio et al., 2010; Diouf, 2001; Sileshi et al., 2011). Therefore, measures that mitigate land degradation are urgently needed to increase water productivity and reduce risks of crop failure under rain-fed maize cropping systems. Integration of legumes into maize cropping systems is one option for mitigating land degradation (Sileshi et al., 2011) as they add considerable amounts of organic matter and nitrogen to the soil (Akinnifesi et al., 2007; Beedy et al., 2010; Mafongoya et al., 2006; Snapp et al., 1998). Over two decades of agroforestry research in southern Africa shows that organic matter added to the system increases structural stability of the soil, resistance to rainfall impact, infiltration rates, and faunal and microbial activities (Beedy et al., 2010; Mafongoya et al., 2006; Sileshi and Mafongoya, 2006). Growing maize in association with legume trees has also been shown 
to increase yields in many parts of SSA (Sileshi et al., 2008; 2010). However, the stability of yields has not been critically analyzed in cropping systems that integrate legume trees, as most of the studies are short-term in nature. Crop yield stability is an important characteristic to be considered when judging the value of a cropping system relative to others (Piepho, 1997; 1998).

In the past, the analysis of yield stability has been largely confined to trials of crop cultivars in multiple environments. However, the application of stability analyses for comparing different agronomic treatments is gaining acceptance (Guertal et al., 1994; Hildebrand, 1983; Piepho, 1998; Raman et al., 2011). The objective of the present analyses was to compare yield stability in improved cropping systems, namely maize-Gliricidia (Gliricidia sepium) intercropping and fertilized monoculture maize, with the de facto practice of resource-poor farmers. Specifically, we test the hypothesis that yields are more stable in maize-Gliricidia intercropping than in fertilized or unfertilized monoculture maize.

\section{MATERIALS AND METHODS}

Data from four long-term trials were used to test this hypothesis. The studies were located in southern Malawi and eastern Zambia (Table 1) At all sites, monoculture maize crops grown without any external inputs (control) was comparison with a fully fertilized maize crop and maize intercropped with Gliricidia (Gliricidia sepium), which is a nitrogen-fixing legume tree. Maize grown without any external input is the de facto resource-poor farmers' practice in Malawi and Zambia, and this was used as the control.

\section{The Study Sites and Treatments}

The first trial was established at Makoka Agricultural Research Station $\left(15^{\circ} 30^{\prime} \mathrm{S}, 35^{\circ} 15^{\prime} \mathrm{E}\right.$; altitude $1030 \mathrm{~m}$ a.s.1.) in southern Malawi and run for 13 consecutive years. The rainfall is unimodal; 
most of which occurs between November and April. The 30-year mean annual rainfall is $1024 \mathrm{~mm}$. The cropping (wet) season extends from October to April. The soil at this site is Ferric Lixisol (FAO) with $46 \%$ sand, $46 \%$ clay and $8 \%$ silt.

This trial was established in December 1991 for studying long-term biophysical performance of Gliricidia intercropping on maize yield. The experimental design was a randomized complete block with three replicates. The treatments consisted of three cropping systems (fertilized maize monoculture, unfertilized maize monoculture and maize-Gliricidia intercropping with and without fertilizer). There were three rates of nitrogen $(\mathrm{N})$ and phosphorus $(\mathrm{P})$ applied as calcium ammonium nitrate (CAN) and triple superphosphate (TSP), respectively. The $\mathrm{N}$ rates were $0,50 \%$ and $100 \%$ of the recommended $92 \mathrm{~kg} \mathrm{~N} \mathrm{ha}^{-1}$. The $\mathrm{P}$ rates were 0,50 and $100 \%$ of recommended $40 \mathrm{~kg} \mathrm{P} \mathrm{ha}^{-1}$ for hybrid maize growing in Malawi. In this analysis, fertilized maize monoculture, maize-Gliricidia intercropping without fertilizer and maize-Gliricidia intercropping with $50 \%$ of the recommended $\mathrm{N}$ and P fertilizer were compared with maize grown without any input (control). Gliricidia seedlings were planted in pure stands at $0.9 \mathrm{~m} \times 1.5 \mathrm{~m}\left(7400\right.$ trees $\left.^{-1} \mathrm{a}^{-1}\right)$. The trees were cut back in September 1992 to the height of $0.30 \mathrm{~m}$. Since then, the re-sprouts from the tree stumps were pruned three times during each cropping season, and leaves and twigs were incorporated in the soil. Maize hybrid NSCM 41 was planted on ridges at a spacing of $30 \mathrm{~cm}$ within rows and $75 \mathrm{~cm}$ between rows $(44,000$ plants $\mathrm{ha}^{-1}$ ), in both the monoculture maize as well as intercropping. The management of this trial has been described in detail in Akinnifesi et al. (2007).

The second and third trials were established at Msekera Research Station $\left(13^{\circ} 39^{\prime} \mathrm{S}, 32^{\circ} 34^{\prime}\right.$ E, altitude $1025 \mathrm{~m}$ ) in eastern Zambia in two separate fields in 1991 and 1992. The trials are code-named Expt 91-3 and Expt 92-3 based on the year of establishment of the experiments and the length of the fallow period (3 years). Both trials had a randomized complete block design with four replicates. These trials were run for 12 consecutive years. The soils at both sites were ferric Luvisols (FAO classification) with $61 \%$ sand, $11 \%$ silt and $28 \%$ clay. The climate of the study area is humid 
subtropical with three distinct seasons: the warm wet season (November to April), the cool winter (May to August) and the hot, dry season (September to October). The rainfall pattern is unimodal (averages $960 \mathrm{~mm}$ per year) with approximately 85\% of the rains falling during December-March. Gliricidia seedlings were planted in pure stands at a spacing of $1 \mathrm{~m}$ by $1 \mathrm{~m}\left(10,000\right.$ trees ha $\left.{ }^{-1}\right)$. At the end of the fallow period (36 months) trees were cut at $0.3 \mathrm{~m}$ height, and the leaf and twig biomass was incorporated into the soil. Since then, the re-sprouts were pruned three to four times every year and pruning biomass was incorporated into the soil. Maize (hybrid MM604) was planted on the ridges between the tree stumps every year. Continuous monoculture maize crops grown with and without fertilizer input were planted for 12 consecutive years in Expt 91-3 and Expt 92-3, respectively. Fertilized monoculture maize received the recommended rate of $200 \mathrm{~kg} \mathrm{ha}^{-1} \mathrm{yr}^{-1}$ compound fertiliser $\left(\mathrm{N}=100 \mathrm{~g} \mathrm{~kg}^{-1}, \mathrm{P}=90 \mathrm{~g} \mathrm{~kg}^{-1}\right.$, and $\left.\mathrm{K}=80 \mathrm{~g} \mathrm{~kg}^{-1}\right)$ at planting and $200 \mathrm{~kg} \mathrm{ha}^{-1}$ urea at four weeks after planting. The management of these trials have been described in detail elsewhere (Sileshi and Mafongoya 2006).

\section{Data and Analysis}

Analysis of variance was conducted on maize yield for each data set using the SAS mixed models procedure with Type 3 option (SAS Institute, 2008). In the model, the treatment (i.e. cropping system) constituted the fixed effect whereas block, year and year $\times$ treatment interactions were the random effects. Wherever the treatment main effect was significant, treatment mean yields were compared using Tukey's test at 5\% level of significance.

In order to assess yield stability, various models were applied to the datasets from the three sites separately. The three datasets could not be combined because the maize varieties and experimental design used were slightly different. Several methods of stability analysis exist, but these generally fall in two broad categories, i.e. those that use either regression or variance methods (Stelluti et al., 2007).In this paper we tested the regression technique as well as three variance models. 
The stability analysis by means of regression consists in relating the performance of a genotype onto an environmental index computed as the mean of all genotypes in an environment (Guertal et al., 1994; Guretzky et al., 2010). The index may be taken as a measure of the productivity of an environment or a year. In this analysis we conducted linear regression of treatment yield on the environment mean yield, calculated as the average yield of all treatments for each year (Grover et al., 2009; Guertal et al., 1994). For a valid stability analysis, changes in yield over time should not differ among the cropping systems being compared (Guertal et al., 1994). A significant treatment mean and year relationship would indicate a long-term trend with respect to the treatment and would preclude the use of stability analysis (Guertal et al., 1994; Guretzky et al., 2010).

A simple linear regression of treatment means on the environmental means for each dataset was conducted using PROC GLM of SAS (SAS Institute, 2008). The significance of regression coefficients for each treatment was determined using 5\% probability level, and then tests of equality of the coefficients were performed using pre-planned comparisons. The slope of the regression line was used as a relative measure of stability, where a smaller slope was interpreted as an indication of greater yield stability (Guertal et al., 1994). The root mean square of error (RMSE) was used to judge the accuracy of estimates from the regression. RMSE is measure of the differences between values predicted by a model and the values actually observed.

Three models, the environmental variance model with unstructured variance-covariance matrix (Piepho, 1998), Shukla's stability variance model (Shukla, 1972) and the Eberhart-Russell regression model (Eberhart and Russell, 1966) were compared. The environmental variance model is the most general model of which the other two are special cases obtained by partitioning the random deviation from the mean $\left(a_{i j}\right)$ as $u_{j}+e_{i j}$ for Shukla's stability variance model and as $\lambda_{i} u_{j}+d_{i j}$ for the Eberhart and Russell model. These models differ in the variance-covariance structure while the expectation structure is identical.

Following Piepho (1998) the environmental variance model can be specified as follows: 
$y_{i j}=\mu_{i}+a_{i j}$

where $y_{i j}(i=1, \ldots, I ; j=1, \ldots, J)$ is the performance of the $\mathrm{i}^{\text {th }}$ treatment in the $\mathrm{j}^{\text {th }}$ environment, $\mu_{i}$ is the mean effect of the $\mathrm{i}^{\text {th }}$ treatment and $a_{i j}$ is a random deviation from the mean of the $\mathrm{i}^{\text {th }}$ treatment in the $\mathrm{j}^{\text {th }}$ environment. The mean effect is the systematic component (i.e. fixed effect), for example the average yields in a cropping system in a given location. This random effect accommodates the average block effect in the $\mathrm{j}^{\text {th }}$ environment, the $\mathrm{ij}^{\text {th }}$ treatment-environment interaction effect and the experimental error term (Piepho, 1999). The $a_{i j}$ 's for the same environment $\mathrm{j}$ are assumed to be correlated. The variance-covariance structure of the vector $\mathbf{a}_{j}=\left(a_{1 j}, \ldots, a_{i j}\right)^{\prime}, \quad \operatorname{var}\left(\mathbf{a}_{j}\right)=\sum$ is completely unstructured, i.e., the elements in the symmetric variance-covariance matrix $\sum$ may take any value, as long as it is positive definite. The diagonal elements of $\sum, \sigma_{i i}$ are environmental variances of the treatments, which may be interpreted as stability measures; the smaller the $\sigma_{i i}$, the more stable the $\mathrm{i}^{\text {th }}$ treatment.

Shukla's stability variance model for the treatment-environment means data can be specified as follows:

$y_{i j}=\mu_{i}+u_{j}+e_{i j}$

where $u_{j}$ is a random environmental main effect and $e_{i j}$ is a random residual comprising both treatment-by-environment interaction and error terms. The random effects $u_{j}$ and $e_{i j}$ are assumed to be independent with variances $\sigma_{u}^{2}$ and $\sigma_{i}^{2}$, respectively. With this assumption, the covariance between observations in an environment is the same for all pairs of observations $\left(\operatorname{cov}\left(y_{i j}, y_{i j^{\prime}}\right)=\sigma_{u}^{2}\right)$ but the variance of an observation varies among treatments as $\left.v a k y_{i j}\right)=\sigma_{u}^{2}+\sigma_{i}^{2}$. The variance $\sigma_{i}^{2}$ is Shukla's (1972) stability variance and a treatment with a small stability variance is considered as stable. 
Eberhart and Russell regression model (1966) for the treatment-environment mean data can be specified as follows:

$y_{i j}=\mu_{i}+\lambda_{i} u_{j}+d_{i j}$

where $\lambda_{i}$ is a regression coefficient corresponding to the $i^{\text {th }}$ treatment and $d_{i j}$ is a random deviation from the regression line. The $u_{j}$ is a latent environmental variable that cannot be measured directly (Piepho, 1998), but to which treatments are assumed to respond linearly, with possible differences in the strength of response indicated by differences in the sensitivity parameter $\lambda_{i}$. The random effects $u_{j}$ and $d_{i j}$ are assumed to be independent with variances $\sigma_{u}^{2}$ and $\sigma_{d(i)}^{2}$. Unlike Shukla's model, the covariance now may vary among pairs of cropping systems as $\operatorname{cov}\left(y_{i j}, y_{i^{\prime} j^{\prime}}\right)=\lambda_{i} \lambda_{i^{\prime}} \sigma_{u}^{2}$. The multiplicative term $\lambda_{i} u_{j}$ is overparameterized, therefore in the analysis the PROC MIXED identifiability constraint $\sigma_{u}^{2}=1$ is used. A treatment with a large absolute value of $\lambda_{i}$ shows large sensitivity to changing environmental conditions. The variance $\sigma_{d(i)}^{2}$ has the interpretation of a variance of deviations from the regression line.

The models were fitted using the MIXED procedure of the SAS system (SAS Institute, 2008) following Piepho (1999). The mixed model perspective implies that trials are conducted at a random sample of environments from a target region. In all cases year was considered as a random environment. This procedure used the Restricted Maximum Likelihood (REML) method for estimating variance components.

Then Akaike's Information Criterion (AIC) was computed to assess the adequacy of the three fitted models. The model with the smallest value of the AIC is considered most desirable (Piepho, 1998). In the present study, however Akaike weights (AICw) were used as AICw has the advantage of being easy to interpret than AIC (Johnson and Omland, 2004). AICw indicates the probability that 
the model is the best among the whole set of candidate models. Therefore, it provides a measure of the strength of evidence for each model (Johnson and Omland, 2004).

\section{RESULTS}

\section{Variation in Yield with Treatment}

Maize yields varied from year to year as indicated by the significant year $\times$ treatment interactions on all sites (Table 2). The yields were also different among the treatments and years. At Makoka, the highest yield was recorded in maize-Gliricidia intercrops amended with $50 \%$ of recommended fertilizer (Table 3). Average yields in fully fertilized monoculture maize were comparable with those in maize-Gliricidia intercropping. The lowest yield was recorded in the maize grown without any external input (control), which is the de facto farmers' practice. At the two sites at Msekera (Expt 913 and Expt 91-3) the highest yield was recorded in fully fertilized monoculture maize. This was followed by maize-Gliricidia intercrops. The lowest yield was recorded in maize grown without any external input. The highest coefficient of variation $(\mathrm{CV})$ was recorded in maize grown without any external input at Msekera, while the opposite was true at Makoka (Table 3). Yields declined over the years in the control and fertilized monoculture maize (data not shown).

\section{Yield Stability}

The regression technique indicated some differences among treatments over time (Table 4). Linear regression of treatment means on the environment means was highly significant $(\mathrm{P}<0.01)$ for the trial at Makoka and Expt 91-3 at Msekera (Table 4). The slopes of the regression of mean yield on year were non-significant $(\mathrm{P}>0.05)$ for Makoka and Expt 91-3 at Msekera. Therefore, stability analysis using the regression technique was deemed acceptable for these sites. However, for Expt 923 the slopes were highly significant indicating unsuitability of stability analysis using the linear 
regression technique (data not shown). Therefore, results are presented only for Makoka and Expt 91-3 datasets (Table 4).

Maize-Gliricidia intercropping had the most stable yields at Makoka (Table 4). The slopes exceeded 1.0 in all treatments except maize-Gliricidia intercropping. Tests of equality of slope (Table 5) indicated significant differences only between maize-Gliricidia intercropping and fertilized maize. However, deviations from regression were smallest (indicated by RMSE) in Gliricidia $+50 \%$ $\mathrm{N}$ fertilizer. Variability around the intercept and slope (indicated by the standard errors) was smaller for Gliricidia $+50 \%$ fertilizer than that for the Gliricidia, fertilized maize and the control (Table 4). Examination of the slopes (Table 4) indicated that maize grown without any external inputs had the most stable yields in Expt 91-3 at Msekera. Variability around the intercept and slope was largest in the fertilizer monoculture maize. Deviations from regression were also larger in the fertilizer monoculture maize than in maize-Gliricidia intercropping and the control (Table 4). Tests of equality of slope (Table 5) indicated no significant differences in all comparisons in Expt 91-3.

For a given variety of maize, the environmental variance was larger when fertilizer was applied (e.g. fertilized maize and Gliricidia $+50 \%$ fertilizer) suggesting that these treatments were not as stable as the maize-Gliricidia intercropping (Table 6). According to the environmental variance model, fully fertilized monoculture maize crop is the least stable in all three trials. Maize-Gliricidia intercrop without fertilizer was the most stable at Makoka. Maize crop associated with Gliricida also had a relatively small regression coefficient $\left(\lambda_{i}\right)$ which indicates least sensitive to changing environmental conditions. The environmental variance and Shukla's stability variance models indicated the highest stability in the control, followed by the maize-Gliricidia intercropping in Expt 91-3 and Expt 92-3 (Table 6). However, the Eberhart and Russell model indicated highest stability in maize-Gliricidia intercropping. In the case of control, parameter estimates had large standard errors indicating that 12-13 environments are not an adequate sample to obtain reliable stability estimates using Shukla's stability variance model. 
According to the model comparisons based on $\mathrm{AICw}$, the best fits were obtained by the environmental variance model for the Makoka site and Eberhart and Russell model for Expt 91-3 and Expt 92-3. The AICw shows that the environmental variance model has a $57 \%$ chance of being the appropriate model for the Makoka dataset relative to a $24 \%$ and $19 \%$ chance for the stability variance and Eberhart and Russell models, respectively (Table 7). The Eberhart and Russell model had 53 and $63 \%$ chance of being the appropriate model for Expt 91-3 and Expt 92-3, respectively (Table 7). Therefore, the Eberhart and Russell stability model was considered the most appropriate for interpreting yield stability on both sites at Msekera. Accordingly, yields were judged to be more stable in maize-Gliricidia intercropping compared to the fertilized monoculture maize at Msekera.

The generalized least squares estimates of $\mu_{i}$ for the various treatments in the three trials are presented in Table 8. While the estimates of $\mu_{i}$ are consistent across the different models, there are differences in standard errors of estimates between models. The standard errors of estimates from the stability variance model were different from those of the Eberhart and Russell and the environmental variance model (Table 8). Based on the model selected using AICw (Table 7), the standard errors provided by the environmental variance model are the most appropriate for the Makoka dataset (Table 8). In the case of Expt 91-3 and Expt 92-3, the most appropriate standard errors are those provided by the Eberhart and Russell model.

\section{DISCUSSION}

The results revealed that intercropping maize with Gliricida can significantly increase maize yield over maize grown without any external inputs in Malawi and Zambia. This may be attributed to the enhancement of nutrient (Akinnifesi et al., 2007; Sileshi and Mafongoya, 2006) and water availability (Chirwa et al. 2007) in the maize-Gliricidia intercrop. The re-sprout biomass (green leaf + twigs) from Gliricidia incorporated in the soil was estimated to add up to $302 \mathrm{~kg} \mathrm{ha}^{-1} \mathrm{~N} \mathrm{yr}^{-1}$ in the trial at Makoka (Akinnifesi et al., 2006) and $124 \mathrm{~kg} \mathrm{ha}^{-1} \mathrm{~N} \mathrm{yr}^{-1}$ in Expt 92-3 at Msekera (Sileshi and 
Mafongoya, 2006). Similarly, the re-sprout biomass was estimated to add up to $21 \mathrm{~kg} \mathrm{P} \mathrm{ha}^{-1} \mathrm{yr}^{-1} \mathrm{at}$ Makoka (Akinnifesi et al., 2006) and up to $8 \mathrm{~kg} \mathrm{P} \mathrm{ha}^{-1} \mathrm{yr}^{-1}$ in Expt 92-3 (Sileshi and Mafongoya, 2006). The pruning biomas has also been shown to increase organic matter (SOM) and faunal activity in the soil (Beedy et al. 2010; Sileshi and Mafongoya, 2006). For example, SOM, particulate organic matter (POM), POM-C and POM-N were 12, 40, 62 and 86\% higher in the maize-Gliricidia intercrop compared to monoculture maize at the Makoka site (Beedy et al. 2010). These increases in SOM and faunal activity in turn may lead to improvements in soil structure and water dynamics. For example, infiltration rates and water use efficiency were higher in the maize-Gliricidia intercrops than monoculture maize at the study sites (Chirwa et al. 2007; Sileshi and Mafongoya, 2006).

Although yields were high in fertilized maize they were unstable in all three trials. This highlights the fact that high yield is not necessarily an indicator of sustained productivity as it may be associated with low stability At the Msekera site, yields in the control and fertilized maize showed declining trend over the years (Sileshi and Mafongoya, 2006). This is in agreement with studies conducted elsewhere. For example, continuous maize cropping of maize with inorganic fertilizer at Ibadan resulted in significant yield decline over a period of 16 years (Vanlauwe et al., 2005). Based on a 14 year study in Punjab, Bhandari et al. (2002) noted decline in rice yield even when the recommended rates of $\mathrm{N}, \mathrm{P}$, and $\mathrm{K}$ were applied. This was attributed to loss of total soil $\mathrm{N}$ and organic matter (Bhandari et al., 2002). Application of fertilizer without addition of organic matter may not be sustainable because only organic matter adds carbon, feeds soil biota and helps to retain soil moisture (Sileshi and Mafongoya, 2006; Sileshi et al., 2011).

The evaluation of yield stability requires use of appropriate measures of variability around a mean. The coefficient of variation (CV) is of limited use as it gives only a relatively simple expression of the variability around a mean yield (Rao and Willey, 1980). The CV could also give a misleading impression as it does not take the covariance structure into account. The concept of stability implies a random (i.e. unpredictable) element in the performance of a cropping system. 
Therefore, we used variance components as they measure variability across environments more efficiently than the CV (Table 3) and the regression technique (Table 4). The mixed modeling framework allows accurate estimation of this random component. While various procedures of stability analysis may be applicable, the results may not always be concordant (Stelluti et al., 2007). One has to use appropriate variance-covariance matrix for valid inferences (Piepho, 1999). The results of the present analyses suggest that the environmental variance model was more suitable for the Makoka trial than the other models. On the other hand, the Eberhart and Russell model was the most suitable for Expt 91-3 and Expt 92-3 datasets. This highlights the need for selecting models appropriate for the data at hand for better interpretation. According to the mixed modeling framework the problem of choosing an appropriate stability measure can be regarded as the problem of identifying the most appropriate variance-covariance structure and this choice is data-dependent. Therefore, the usefulness of any measure of stability depends crucially on how well the underlying model approximates the real data (Piepho, 1998). However, this difference does not always happen. The major advantage of mixed model approach is its applicability to unbalanced data for stability measures by using restricted maximum likelihood (REML) method. The data may be unbalanced owing to missing observations on some plots, varying number of replications among trials and some cropping system by environment combinations that may not be tested.

To our knowledge this is the first study of its kind that analyzed long-term trends in crop yield stability in cereal-legume tree associations in southern Africa. In fact most of the studies assessing cereal-legume tree associations are short term (see Sileshi et al., 2008). As highlighted by a review of intercropping studies (Connolly et al., 2001), concerns about stability and sustainability are not as central in many of the intercropping studies as might have been expected. Short-term studies do not allow one to identify reliable cropping systems, i.e. those that combine high levels of mean yield and yield stability. It is also not possible to determine with any degree of certainty trends in soil processes or weather changes with short-term studies (Girma et al., 2007). The large standard errors 
of the variance estimates observed in most of the treatments indicate that 12-13 environments are not an adequate sample to obtain reliable stability estimates. This emphasizes the need for long-term monitoring of maize yield in the cropping systems investigated. The value of long-term monitoring in revealing dynamic soil processes has been demonstrated (Davis et al., 2003; Edmeades, 2003; Girma et al., 2007; Miles and Brown, 2011) in studies ranging from 20 to 120 years in the USA and Europe. Such long-term studies are virtually non-existent in SSA.

Understanding temporal variability in crop yields has implications for sustainable crop production and food security in Africa. Long-term trials are vital for identifying cropping systems with high and stable crop yields and low production risk (Grover et al., 2009). Such experiments now have additional and immediate relevance for understanding and predicting the consequences of global change taking place in Africa. A network of long-term trials may also provide useful information on the vulnerability of staple crops and current management practices to future changes. The value of such trials has recently been demonstrated by Lobell et al. (2011) on the effects of potential warming on African maize. Therefore, we recommend establishment of well-designed long-term trials that allow stability analyses to help in assessing current and expected vulnerabilities of cropping systems with a changing climate in Africa. Such information can help in exploring possible technological alternatives and policy interventions to improve the adaptability and sustainability of cropping systems.

\section{References}

Akinnifesi, F.K., W. Makumba, and F.R. Kwesiga. 2006. Sustainable maize production using gliricidia/maize intercropping in southern Malawi. Exp. Agr. 42: 441-457.

Akinnifesi, F.K., W. Makumba, G. Sileshi, O.C. Ajayi, and D. Mweta. 2007. Synergistic effect of inorganic N and P fertilizers and organic inputs from Gliricidia sepium on productivity of intercropped maize in Southern Malawi. Plant Soil 294: 203-217. 
Beedy, T.L., S.S. Snapp, F.K. Akinnifesi, and G.W. Sileshi. 2010. Impact of Gliricidia sepium intercropping on soil organic matter fractions in a maize-based cropping system. Agr. Ecosyst. Environ. 138: 139-146.

Bhandari, A.L., J.K. Ladha, H. Pathak, A.T. Padre, D. Dawe, and R.K. Gupta. 2002. Yield and soil nutrient changes in a long-term rice-wheat rotation in India. Soil Sci. Soc. Am. J. 66: 162170.

Bossio, D., K. Geheb, and W. Critchley. 2010. Managing water by managing land: Addressing land degradation to improve water productivity and rural livelihoods. Agr. Water Manage. 97: $536-542$.

Chirwa, P.W., C.K. Ong, J. Maghembe, and C.R. Black. 2007. Soil water dynamics in cropping systems containing Gliricidia sepium, pigeon pea and maize in southern Malawi. Agroforest. Syst. 69: 29-43.

Connolly, J, H.C. Goma, and K. Rahim. 2001. The information content of indicators in intercropping research. Agr. Ecosyst. Environ. 87: 191-207.

Davis, R.L., J.J. Patton, R.K. Teal, Y. Tang, M.T. Humphreys, J. Mosali, K. Girma, J.W. Lawles, S.M. Moges, A. Malapati, J. Si, H. Zhang, S. Deng, G.V. Johnson, R.W. Mullen, and W.R. Raun. 2003. Nitrogen balance in the Magruder plots following 109 years in continuous winter wheat. J. Plant Nutr. 26: 1561-1580.

Diouf, A. 2001. Monitoring land-cover changes in semi-arid regions: remote sensing data and field observations in the Ferlo, Senegal. J. Arid Environ. 48: 129-148.

Dixon, J., A. Gulliver, and D. Gibbon. 2001. Farming systems and poverty: Improving farmers livelihoods in a changing world. FAO, Rome \& World Bank, Washington DC.

Eberhart, S.A., and W.A. Rusell. 1966. Stability parameters for comparing varieties. Crop Sci. 6: 3640. 
Edmeades, D.C. 2003. The long-term effects of manures and fertilisers on soil productivity and quality: a review. Nutr. Cycl. Agroecosyst. 66: 165-180.

Girma, K., S.L. Holtz, D.B. Arnall, B.S. Tubaña, and W.R. Raun. 2007. The Magruder Plots: Untangling the puzzle. Agron. J. 99: 1191-1198.

Grover, K.K., H.D. Karsten, and G.W. Roth. 2009. Corn grain yields and yield stability in four longterm cropping systems. Agron. J. 101: 940-946.

Guertal, E. A., W.R. Raun, R.L. Westerman, and R.K. Boman. 1994. Applications of stability analysis for single-site, long term experiments. Agron. J. 86: 1016-1019.

Guretzky, J., M. Kering, J. Mosali, E. Funderburg, and J. Biermache. 2010. Fertilizer rate effects on forage yield stability and nutrient uptake of midland bermudagrass. J. Plant Nutr. 33: 18191834.

Hildebrand, P.E. 1983. Modified stability analysis of on-farm trials. Agron. J. 76: 271-274.

Johnson, J. B., and K. S. Omland. 2004. Model selection in ecology and evolution. Trends Ecol. Evol. 19: 101-108.

Lobell, D.B., M. Bänziger, M.C. Magorokosho, and B. Vivek. 2011. Nonlinear heat effects on African maize as evidenced by historical yield trials. Nat. Clim. Change 1: 42-45.

Mafongoya, P.L., E. Kuntashula, and G. Sileshi. 2006. Managing soil fertility and nutrient cycles through fertilizer trees in southern Africa. P. 273-289. In Uphoff, N, Ball, A.S., Fernandes, E., Herren, H., Husson, O., Liang, M., Palm, C., Pretty, J., Sanchez, P., Sanginga, N., Thies, J. (eds) Biological approaches to sustainable soil systems. Taylor \& Francis.

Miles, R.J., and J.R. Brown. 2011. The Sanborn field experiment: Implications for long-term soil organic carbon levels. Agron. J. 103: 268-278.

Munthali, W.W. 2007. Integrated Soil Fertility Management Technologies: A Counteract to Existing Milestone in Obtaining Achievable Economical Crop Yields in Cultivated Lands of Poor Smallholder Farmers in Malawi. P. 531-536. In Bationo, A., B. Waswa, J. Kihara, J. Kimetu 
(eds) Advances in integrated soil fertility management in sub-Saharan Africa: Challenges and opportunities. Springer, The Netherlands.

Piepho, H.P. 1997. Analyzing genotype-environment data by mixed models with multiplicative terms. Biometrics 53: 761-766.

Piepho, H.P. 1998. Methods for comparing the yield stability of cropping systems. J. Agron. Crop Sci. 180: 193-213.

Piepho, H.P. 1999. Stability analysis using the SAS system. J. Agron. 91: 154-160.

Raman, A., J.K. Ladha, V.Kumar, S. Sharma, and H.P. Piepho. 2011. Stability analysis of farmer participatory trials for conservation agriculture using mixed models. Field Crop Res. 121: $450-459$.

Rao, M. R., and R. W. Willey. 1980. Evaluation of Yield Stability in Intercropping: Studies on Sorghum/Pigeonpea. Experimental Agriculture 16: 105-116.

Sanchez, P.A. 2002. Soil fertility and hunger in Africa. Science 295: 2019-2020.

SAS Institute, 2008. SAS/STAT Release 9.2, Cary, NC: SAS Institute Inc.

Shukla, G.K. 1972. Some statistical aspects of partitioning genotype-environmental components of variability. Heredity 29: 237-245.

Sileshi, G., and P.L. Mafongoya. 2006. Long-term effect of legume-improved fallows on soil invertebrates and maize yield in eastern Zambia. Agr. Ecosyst. Environ. 115: 69-78.

Sileshi, G., F.K. Akinnifesi, O.C. Ajayi, and F. Place. 2008. Meta-analysis of maize yield response to planted fallow and green manure legumes in sub-Saharan Africa. Plant Soil 307: 1-19.

Sileshi, G., F.K. Akinnifesi, L.K. Debusho, T. Beedy, O.C. Ajayi, and S. Mong’omba. 2010. Variation in maize yield gaps with plant nutrient inputs, soil type and climate across subSaharan Africa. Field Crop Res. 116: 1-13. 
Sileshi, G.W., F.K. Akinnifesi, O.C. Ajayi, and B. Muys. 2011. Integration of legume trees in maizebased cropping systems improves rainfall use efficiency and crop yield stability. Agr. Water Manage. 98: 1364-1372.

Snapp, S.S., P.L. Mafongoya, and S.R. Waddington. 1998. Organic matter technologies to improve nutrient cycling in small holder cropping systems of southern Africa. Agr. Ecosys. Environ. 71: 187-202.

Stelluti, M., A. Caliandro, and A.M. Stellacci. 2007. Influence of previous crop on durum wheat yield and yield stability in a long-term experiment. Ital. J. Agron. 3: 333-339.

Vanlauwe, B., J. Diels, N. Sanginga, and R. Merckx. 2005. Long-term integrated soil fertility management in South-western Nigeria: Crop performance and impact on the soil fertility status. Plant Soil 273: 337-354.

Wani, S.P., P. Singh, K. Boomiraj, and K.L. Sahrawat. 2009. Climate change and sustainable rainfed agriculture: challenges and opportunities. Agric. Sit. India 66: 221-239. 
Table 1. Baseline soil properties (top $20 \mathrm{~cm}$ ) of the study sites at Makoka Agricultural Research Station in Malawi and Msekera Research Station in Eastern Zambia

\begin{tabular}{lll}
\hline Soil properties & Makoka site & Msekera sites \\
\hline Soil type $(\mathrm{FAO})$ & Ferric Lixisols & Ferric Luvisols \\
Sand $(\%)$ & 46 & 61 \\
Clay $(\%)$ & 46 & 28 \\
Organic C $\left(\mathrm{g} \mathrm{kg}^{-1}\right)$ & 8.8 & 10.2 \\
$\mathrm{pH}\left(\mathrm{H}_{2} \mathrm{O}\right)$ & 5.9 & 5.3 \\
$\mathrm{Mg}(\mathrm{c} \mathrm{mol} / \mathrm{cg})$ & 1.6 & 1.7 \\
$\mathrm{Ca}(\mathrm{c} \mathrm{mol} / \mathrm{kg})$ & 4.4 & 3.0 \\
$\mathrm{~K}(\mathrm{c} \mathrm{mol} / \mathrm{cg})$ & 0.3 & 1.5 \\
\hline
\end{tabular}

Table 2. Type 3 analysis of variance for maize yield in cropping systems (Treatment) at Makoka Agricultural Research Station in Malawi, and in Expt 91-3 and Expt 92-3 at Msekera Research Station in Eastern Zambia

\begin{tabular}{lllllll}
\hline Source of & Makoka & \multicolumn{2}{l}{ Expt 91-3 } & \multicolumn{2}{c}{ Expt 92-3 } \\
\cline { 2 - 7 } Variation & DF & MS & DF & MS & DF & MS \\
\hline Block & 2 & $4.09^{* *}$ & 3 & $0.45 \mathrm{~ns}$ & 3 & $4.86^{* * *}$ \\
Year & 12 & $26.88^{* * *}$ & 11 & $3.95^{* *}$ & 11 & $8.22^{* * *}$ \\
Treatment & 3 & $27.82^{* * *}$ & 2 & $107.34^{* * *}$ & 2 & $118.53^{* * *}$ \\
Year $\times$ Treatment & 36 & $2.65^{* * *}$ & 22 & $0.95^{* *}$ & 22 & $1.71^{* * *}$ \\
Residual & 102 & 0.743 & 93 & 0.46 & 105 & 0.48 \\
\hline
\end{tabular}

$\mathrm{DF}=$ degrees of freedom; MS = mean square

** Significant at the 0.01 probability level.

*** Significant at the 0.001 probability level.

ns $=$ Non significant

Table 3. Mean maize yields $\left(\mathrm{Mg} \mathrm{ha}^{-1}\right)$ in various treatments at Makoka Agricultural Research Station in Malawi, and Expt 91-3 and Expt 92-3 at Msekera Research Station in Eastern Zambia

\begin{tabular}{llll}
\hline Treatment $^{\#}$ & Makoka & Expt 91-3 & Expt 92-3 \\
\hline Control & $2.62(29.0) \mathrm{a}^{+}$ & $1.20(66.7) \mathrm{a}^{+}$ & $0.98(56.1) \mathrm{a}^{+}$ \\
Fertilizer & $4.17(34.8) \mathrm{bc}$ & $4.42(31.4) \mathrm{c}$ & $4.08(40.7) \mathrm{c}$ \\
Gliricidia & $3.72(41.9) \mathrm{b}$ & $3.06(46.7) \mathrm{b}$ & $2.95(40.7) \mathrm{b}$ \\
Gliricidia $+50 \% \mathrm{~F}$ & $4.58(32.5) \mathrm{c}$ & NA & NA
\end{tabular}

${ }^{\#}$ Treatments: Control = unfertilized continuous monoculture maize; Gliricidia = maize-Gliricidia intercropping without fertilizer; Fertilizer $=$ fertilized continuous monoculture maize; Gliricidia $+50 \% \mathrm{~F}=$ maize-Gliricidia intercroping + $50 \%$ of the recommended fertilizer

${ }^{+}$Figures in parentheses are coefficients of variation. These were included upon request by the editor.

Means followed by the same letter in a column are not significantly different according to Tukey's test at 0.05 probability level.

NA $=$ not applicable 
Table 4. Linear regressions for treatment mean maize yield on the environmental mean yields at Makoka Agricultural Research Station in Malawi, and Expt 91-3 and Expt 92-3 at Msekera Research Station in Eastern Zambia

\begin{tabular}{lllllllll}
\hline Experiment & Treatment $^{\#}$ & Intercept & SE & Slope & SE & $\mathrm{R}^{2}$ & RMSE & $P>|t|^{*}$ \\
\hline Makoka & Gliricidia & 1.189 & 0.808 & 0.671 & 0.200 & 0.505 & 1.039 & 0.0065 \\
& Fertilizer & -0.441 & 0.586 & 1.222 & 0.145 & 0.866 & 0.753 & $<0.0001$ \\
& Gliricidia $+50 \% \mathrm{~F}$ & 0.480 & 0.380 & 1.087 & 0.094 & 0.924 & 0.489 & $<0.0001$ \\
& Control & -1.214 & 0.604 & 1.016 & 0.150 & 0.807 & 0.777 & $<0.0001$ \\
Expt 91-3 & Gliricidia & -0.402 & 0.483 & 1.197 & 0.164 & 0.856 & 0.308 & $<0.0001$ \\
& Fertilizer & 1.087 & 0.725 & 1.151 & 0.246 & 0.709 & 0.462 & 0.0011 \\
& Control & -0.699 & 0.568 & 0.657 & 0.192 & 0.564 & 0.362 & 0.0077 \\
\hline
\end{tabular}

${ }^{\#}$ Treatments: Control = unfertilized continuous monoculture maize, Gliricidia = maize-Gliricidia intercropping without fertilizer; Fertilizer $=$ fertilized continuous monoculture maize; Gliricidia $+50 \% \mathrm{~F}=$ maize-Gliricidia intercroping + $50 \%$ of the recommended fertilizer

RMSE $=$ root mean square of error

${ }^{*} P>|t|$ probability of a greater absolute value of $t$ for slope.

Table 5. Tests of equality of slopes among treatments at Makoka Agricultural Research Station in Malawi, and Expt 91-3 at Msekera Research Station in Eastern Zambia

\begin{tabular}{lll}
\hline Experiment & Comparison $^{\#}$ & $P>F^{*}$ \\
\hline Makoka & Gliricidia vs. Gliricidia $+50 \% \mathrm{~F}$ & 0.0597 \\
& Gliricidia $+50 \%$ F vs. Fertilizer & 0.5328 \\
& Fertilizer vs. Control & 0.3439 \\
& Gliricidia vs. Fertilizer & 0.0139 \\
& Gliricida vs. Control & 0.1156 \\
& Gliricidia $+50 \%$ F vs. Control & 0.7444 \\
Expt 91-3 & Overall & 0.0822 \\
& Gliricidia vs. Fertilizer & 0.8731 \\
& Fertilizer vs. Control & 0.0974 \\
& Gliricida vs. Control & 0.0712 \\
& Overall & 0.1340 \\
\hline
\end{tabular}

\# Overall, equality of slopes among cropping systems;

Control $=$ unfertilized maize .

${ }^{*} P>F$, probability of a greater $F$ statistic. 
Table 6. REML parameter estimates (standard errors in parenthesis) of the variance-covariance structure of different stability models for the datasets from Makoka Agricultural Research Station in Malawi, and Expt 91-3 and Expt 91-3 at Msekera Research Station in Eastern Zambia

\begin{tabular}{llllll}
\hline Experiment & Treatment $^{\#}$ & $\begin{array}{l}\text { Environmental } \\
\text { variance, } \sigma_{i i}\end{array}$ & $\begin{array}{l}\text { Shukla's stability } \\
\text { variance }\left(\sigma_{i}^{2}\right)\end{array}$ & $\begin{array}{l}\text { Eberhart- } \\
\text { Russell }\left(\sigma_{i}^{2}\right)\end{array}$ & $\begin{array}{l}\text { Eberhart- } \\
\text { Russell }\left(\lambda_{i}\right)\end{array}$ \\
\hline Makoka & Control & $2.87(1.17)$ & $0.81(0.46)$ & $0.67(0.36)$ & $1.49(0.39)$ \\
& Fertilizer & $3.87(1.58)$ & $0.69(0.36)$ & $0.40(0.39)$ & $1.86(0.43)$ \\
& Gliricidia & $2.00(0.82)$ & $1.58(0.72)$ & $1.32(0.60)$ & $0.83(0.40)$ \\
& Gliricidia $+50 \% \mathrm{~F}$ & $2.87(1.17)$ & $0.23(0.24)$ & $0.35(0.31)$ & $1.59(0.38)$ \\
Expt 91-3 & Control & $0.27(0.12)$ & $0.09(0.09)$ & $0.14(0.06)$ & $0.36(0.15)$ \\
& Fertilizer & $0.66(0.30)$ & $0.45(0.25)$ & $0.38(0.17)$ & $0.53(0.23)$ \\
& Gliricidia & $0.59(0.27)$ & $0.23(0.14)$ & 0 & $0.77(0.17)$ \\
& Control & $0.32(0.135)$ & $0.02(0.084)$ & $0.14(0.061)$ & $0.42(0.145)$ \\
& Fertilizer & $1.84(0.785)$ & $1.30(0.597)$ & $0.86(0.366)$ & $0.99(0.350)$ \\
& Gliricidia & $0.76(0.322)$ & $0.33(0.171)$ & 0 & $0.87(0.185)$ \\
\hline
\end{tabular}

${ }^{\#}$ Treatments: Control = unfertilized continuous monoculture maize, Gliricidia = maize-Gliricidia intercropping without fertilizer; Fertilizer $=$ fertilized continuous monoculture maize; Gliricidia $+50 \% \mathrm{~F}=$ maize-Gliricidia intercroping + $50 \%$ of the recommended fertilizer

A small variance ( $\sigma_{i}^{2}$ value) indicates high relative stability.

Table 7. Akaike's Information Criterion (AIC) and Akaike weights (AICw) for the three models fitted to the datasets from Makoka in Malawi, and Expt 91-3 and Expt 92-3 at Msekera Research Station in Eastern Zambia

\begin{tabular}{llll}
\hline Experiment & Model & AIC & AICw \\
\hline Makoka & Environmental variance & 171.4 & 0.568 \\
& Stability variance & 173.1 & 0.243 \\
& Eberhart and Russell & 173.6 & 0.189 \\
Expt 91-3 & Environmental variance & 69.8 & 0.216 \\
& Stability variance & 69.5 & 0.251 \\
Expt 92-3 & Eberhart and Russell & 68.0 & 0.532 \\
& Environmental variance & 86.9 & 0.242 \\
& Stability variance & 88.1 & 0.133 \\
& Eberhart and Russell & 85.0 & 0.625 \\
\hline
\end{tabular}

Table 8. REML estimates of maize yields $\left(\mathrm{Mg} \mathrm{ha}^{-1}\right)$ and standard errors (in parenthesis) for different stability models of the datasets from Makoka Agricultural Research Station in Malawi, and Expt 91-3 and Expt 91-3 at Msekera Research Station in Eastern Zambia

\begin{tabular}{lllll}
\hline Experiment & Treatment & $\begin{array}{l}\text { Environmental } \\
\text { variance } \mu_{i}\end{array}$ & $\begin{array}{l}\text { Stability } \\
\text { variance } \mu_{i}\end{array}$ & $\begin{array}{l}\text { Eberhart- } \\
\text { Russell } \mu_{i}\end{array}$ \\
\hline Makoka & Control & $2.62(0.470)$ & $2.62(0.502)$ & $2.62(0.470)$ \\
& Fertilizer & $4.17(0.546)$ & $4.17(0.493)$ & $4.17(0.546)$ \\
& Gliricidia & $3.72(0.392)$ & $3.72(0.558)$ & $3.72(0.392)$ \\
Expt 91-3 & Gliricidia $+50 \% \mathrm{~F}$ & $4.58(0.470)$ & $4.58(0.455)$ & $4.58(0.470)$ \\
& Control & $1.20(0.157)$ & $1.20(0.170)$ & $1.20(0.157)$ \\
& Fertilizer & $4.42(0.245)$ & $4.42(0.248)$ & $4.42(0.245)$ \\
Expt 92-3 & Gliricidia & $3.07(0.232)$ & $3.07(0.205)$ & $3.07(0.232)$ \\
& Control & $0.98(0.163)$ & $0.98(0.165)$ & $0.98(0.163)$ \\
& Fertilizer & $4.08(0.392)$ & $4.08(0.367)$ & $4.08(0.392)$ \\
& Gliricidial & $2.95(0.251)$ & $2.95(0.229)$ & $2.95(0.251)$ \\
\hline
\end{tabular}

